\title{
ANALYSIS OF CODE SWITCHING BY EFL STUDENT AT ENGLISH LANGUAGE EDUCATION
}

\author{
Ni Putu Trisna Sariputri \\ Ganesha University of Education \\ e-mail: putritris26@gmail.com
}

\begin{abstract}
This study discusses code switching used by the English Language Education students in their daily communication. This study also tries to find out the factor of applying code switching. The data was collected from around forty participants by using two methods such as observation and interview. The participants were the English Language Education students at Universitas Pendidikan Ganesha. From all of the participants, there were twenty expressions of code switching were revealed. The result shows that the students uses three types of linguistics level in code swicthing such as word level, phrase level and clause or sentence level. It is also found that there are two factors that made the students switch the one language into another language.
\end{abstract}

Keywords: Linguistics Level, Code Switching,

\section{INTRODUCTION}

Nowadays, using two or more languages in daily communication is not a strange thing. People can use two languages to express what they want to say or deliver to the other people. When a person switches a language into another in a conversation, it is called by code-switching (Moghadam, Samad, \& Shahraki, 2012). They also stated that the code switching does not only occur in a whole sentence, but it also can be occurred in phrase or word. There are percentages of codeswitching in a natural communication such as eighty-four percents of single word-switches, ten percents phrase switches and six percent clause switches (Skiba, 1997). The daily life, the code-switching is commonly used in the informal situation and rarely used in written language. It is supported by the result of study by Goodman, Goodman \& Flores (1979). It is found that there were none of the people or students switched the language in written language but they used it in spoken language.

The code switching is commonly applied by the students at Universitas Pendidikan Ganesha especially those who take the English Language Education. Their native language is Bahasa Indonesia, but then they learn English formally in the university. Because of learning English everyday, they are getting used to apply English in their daily conversation but it is very rarely they use the target language fully in conversation. They usually switch those two languages in their daily conversation. The code switching which is applied of the students is varied based on the linguistics structure and level. It depends on the students speaking style and ability.

That term is interesting to be analyzed because there is a theory about the level of code switching by Cook (1991). The researcher investigates the utterance which consists of code switching and then relates it to the theory. Besides, it is also interesting to find out the factor of using the code switching. This aim is supported by the theory about the social factor of code switching by Becker (1997) in his article entitles "Spanish/English Bilingual Code Switching: A Syncretic Model". It is a little bit different from the research which was conducted by Zainuddin (2016). Since the subjects are the EFL students, the researcher wants to analyze the influence of the application of code switching in the daily communication toward their achievement in the formal class. This study describes the use and reasons of using code switching by English 
Language Education students at Universitas Pendidikan Ganesha.

\section{LITERATURE REVIEW Unit of Language}

There are six units of language such as phonemes, words, phrase, clause, sentence and text. In this research, the writer would like to find the level of code switching (the word, phrase and clause or sentence level). The following are the explanation of word, phrase, clause or sentence according to Meyer, (2009) in his book entitle "Second Language learning and Language Teaching".
a. Word : Word is a meaningful combination phonemes.

b. Phrase : A group of words which already has got meaning but does not contain subject and predicates in it and it is still a part of sentence.

c. Clause : A group of words which has already got meaning, contains subject and predicates, but it still a part of sentence.

d. Sentence : A group of word which has already got a meaning and contains a subject and predicates.

\section{Code Switching}

Code switching is a particular feature of bilinguals which is related to situation where bilingual persons alternate between languages or within utterance (Greer, 2007). The codes are usually in the varieties of language which is used by members of a language community. For the monolingual, codes are the varieties of same language while in the bilingual the codes refer to the varieties of two languages. The language has some classes of variety such as dialect, speech level and style but in this research, the writer tend to be more focus on the linguistics level in the code switching which is used by the EFL students.

According to Richard (1985) in his book entitled "Principle of particle Construction", usually people apply the code switching in the informal situation when the speaker is not paying too much attention to the particular attention to pronunciation, choice of words or sentence structure. Although they use the code switching in their informal situation, one of the causes of its application is the formal education in the university. Besides, the application of code switching in the informal situation also can influence their English ability in the formal education. It already becomes a habit of the EFL students to switch their target language into the native language or the opposite.

\section{Habit of Code Switching}

According to Milroy and Myusken (1995), there are three types of code switching. The first one is Sentential Code Switching which means that it occurs between utterances said by the speakers. The second one is the Intrasentential Code-Switching which takes place within a sentence. The third one is the Suprasentential Code-Switching which occurs when the speaker switch a single item of the utterance. This research will more focus on the second type of code switching. It means that the study is conducted to find out the linguistics levels which take place in the sentence within the conversation. This aim is supported by a theory of code-switching level by Cook (2001) which describes the three levels of codeswitching such as word, phrase and clause level.

\section{Social Factor of Code Switching}

Besides that, there are also three factors of using code switching. Becker, (1997) separates the factors that make bilingual speakers switch codes in to three types: structural linguistics factors, internal psycholinguistics factors, and external social factors.

1) The structural linguistics factor is the ability of the speaker to keep the grammatical coherence of the both languages in the same time.

2) The internal psycholinguistics factor consist of two factors such as:

a. Unconscious factors which contain a brief inclination, exposure frequency, and cultural untranslatability.

b. Conscious factors, which consist of an intention for emphasis, mode, controlling address, personalization, objectification. 
3) The external social factor is an external and social nature such as participants, topic, setting and conditions.

Related on this theory, the writer also wants to find out the reason of why the students apply the code switching in their informal communication. After that the writer analyzes whether it belongs to the first, second or the third factor.

\section{METHOD}

\section{Object of Study}

In doing this study, the writer has three main objects of study. The first one is to identify and analyze the level of codeswitching. In this objective of study, the writer wants to find out the level of code-switching which is used by the students of English Language Education and relates it to the theory of code switching level by Cook, V (1991). The second one is to find the factors which influence the reasons of using code switching. After finding the reasons, the writer will relate it to the theory of code-switching factors by Becker (1997). The third one is to find the influence of switching codes in daily communication toward the students' achievement in formal class. In this objective of study, the writer wants to know the habit of switching language in daily conversation can influence or improve the students' achievement in the class or not. If there are some influences will be found, the writer also wants to know how far the influence is. Those are the three aims of this study which will be conducted.

\section{Participant}

In doing the research, the writer needs some participants in order to collect the data. In this research, the participants or the subject of the research are the students of English Language Education at Universitas Pendidikan Ganesha. Most of them are 19 until 22 years old. The reason of choosing them is because in their age, they learn English in the campus and it becomes a habit to use both of the native language and English in daily conversation among them. There are about forty students which will be observed and interviewed. Ten students from the second semester, ten students from the fourth semester, ten students from the sixth semester and the rest are from the eighth semester. All of the participants are the students who usually switch the codes of their native language to English in daily communication in the class, campus, or in their social media.

\section{Procedure of Data Collection}

The process of collecting data takes place in Singaraja, especially around English Language Education building in Universitas Pendidikan Ganesha. To collect the data, in the study, the writer will use three methods such as observation, documentation and interview. The first one is observation. By using this method, the writer can collect the data by taking a note and hearing the conversation of students who usually switch two languages in a conversation. This method is chosen because it is appropriate to analyze the utterance which is produced by the students because it can help the researcher does the work directly in the field. The second one is documentation. By using this method, the researcher finds out the post or comment of the students in the social media and takes a screen shoot about it. The researcher also can record the conversation of the students and makes it as a documentation of the study. The third one is interview. By using this method, the participant is questioned by the researcher. They are questioned about the reasons of why they apply the code switching in their utterance of conversation. Besides, it can be used to ask the students about the fluency of using code switching in daily conversation toward their achievement in the formal class. By questioning them, they can give their point of view, perception and opinion toward the code switching. They also can explain the reason of using it in their daily communication.

\section{Instrument}

After choosing the method of conducting the study, the researcher also prepares the instrument which helps to use the method. The instruments which are used such as: a smart phone, note, list of questions. The 
smart phone is used to record the students' conversation. The note is used to take a note of the utterance of the students while they are doing conversation. The list of questions become the main item in conducting the interview to the participants. Those are the main instrument which is used in conducting this study.

\section{Data}

The note and record which are collected in the observation become the data of the study. It will be typed and grouped based on their similarities and resemblance. The result of the documentation such as the record and the screenshot also becomes a data which will be described in written form. The answer of students in the interview method also becomes a data which also will be typed. All of the result of the collecting data will be showed in the written form and table. Those are the material that can be analyzed by the researcher in order to reach the aims of the study.

\section{Data Analysis}

The data which have been collected in the study will be analyzed in several ways. The first one is grouping the result of the observation and documentation will be analyzed by listing and grouping the utterances based on the linguistics structure. After that the data will be differentiated based on the linguistics level such as word, phrase and sentence. The data which is collected by interview will be analyzed by grouping them based on the similarities and resemblance of the students' answer.

\section{FINDING AND DISCUSSION}

The use of code-switching by ELE students in their daily communication.

In order to analyze the level of code switching, the writer have found some data in form of expression by using observation method. It is found that around twenty expressions from forty participants. Here are the expressions that have been selected.

(1) I love you sayangku.
(2) Kamu hari ini online tidak?

(3) Aku ke kelas duluan ya karena ada something have to be done.

(4) Yuk pulang, see you tomorrow ya.

(5) Application formnya sudah dilengkapi belum?

(6) Ada yang sudah buat assignment belum?

(7) Kamu udah send e-mail ke Bu Sinta belum?

(8) Yuk having lunch.

(9) I don't know why kepalaku pusing sekali hari ini.

(10) Sudah lama sekali tidak bertemu. I really miss you.

(11) Anytime kita buat tugas di cafe baru itu yuk.

(12) Gantungan kunci itu cute banget deh, aku pengen beli.

(13) I belum mengerti part yang ini. You bisa jelasin gak?

(14) Aku bingung memulai membuat tugas ini darimana. I do not know what I have to do.

(15) Aku selalu malu bicara di depan umum karena aku tidak punya self confidence yang bagus.

(16) Wait sebentar ya, ini masih On the Way.

(17) Kamu udah ngumpul paper belum?

(18) Pak Wahyu sekarang bisa attends the class gak ya?

(19) Kamu bisa mengerjakan tugas practice tiga?

(20) Dressmu elegant dan beautiful banget.

In the analysis below, it only take three sentences as the example analysis. The sentences were chosen selectively in order to make it appropriate toward the discussion topic.

\section{a. Code Switching in Word Level}

"I belum mengerti part yang ini. You bisa jelasin gak?" 
Table 1. Code Switching in Word level

\begin{tabular}{cccccc}
\hline CS & Indonesian Expression & CS & Indonesian Expression & CS & Indonesian Expression \\
\hline I & Belum mengerti & part & Yang ini. & you & bisa jelasin gak? \\
\hline
\end{tabular}

The linguistics level of that kind of code switching is word level. The speaker just change the word saya becomes "I", bagian become "part" and kamu becomes "you" in English. The linguistics changing is in the subject and object. According to Meyer (2009), a meaningful combination of phonemes is called by a word. Based on that theory, those words (I, part and you) belong to word. "I" and "You" are the pronoun and their positions are as the subject of those sentences while the word "part" is a noun and it is as an object the first sentence.

\section{b. Code switching in Phrase Level}

"Aku selalu malu bicara di depan umum karena aku tidak punya self confidence yang bagus."

The linguistics level of that kind of code switching is phrase level. The speaker switched kepercayaan diri in Bahasa Indonesia becomes "self condifence" in English. according to Meyer (2009), a group words which has already got meaning but does not contain subject and predicates in it and it is still a part of sentence is called by Phrase. Based on this theory, it can be concluded that the code switching above is in the phrase level.

Tabel 2. Code Switching in Phrase level

\begin{tabular}{ccc}
\hline Indonesian Expression & CS & Indonesian Expression \\
\hline $\begin{array}{c}\text { Aku selalu malu bicara di } \\
\text { depan umum karena aku } \\
\text { tidak punya }\end{array}$ & $\begin{array}{c}\text { self } \\
\text { confidence }\end{array}$ & yang bagus. \\
\hline
\end{tabular}

\section{c. Code switching in Clause and Sentence Level}

"Aku bingung memulai membuat tugas ini darimana. I do not know what I have to do."

Table 3. Code Switching in Sentence Level

\begin{tabular}{cc}
\hline Indonesian Expression & CS \\
\hline $\begin{array}{c}\text { Aku bingung memulai membuat tugas ini } \\
\text { darimana. }\end{array}$ & $\begin{array}{c}\text { I do not know what I } \\
\text { have to do. }\end{array}$ \\
\hline
\end{tabular}

The linguistics level of that code switching is the clause and sentence level. The speaker switched all of the elements of sentence such as the subject, predicate and also the object. Saya tidak tahu in Indonesia is switched becomess "I do not know". According to Meyer (2009) theory, it belongs to Sentence because it has a subject and predicate. "I" as the subject, "do not know" as the predicate. Apa yang harus saya lakukan in Bahasa Indonesia is switched becomes "What I have to do". It belongs to clause because it is a group of word that has a subject and predicate but still a part of the sentence.

All of the levels are applied by the students in their daily conversation. They can use it in the correct position such as the subject, object or predicates. Besides that they also can put the code switching product in the correct form such as the noun, pronoun, adjective, verb and adverb. The same result of this study was also found by Zainuddin (2016) and it was written in his article entitle "Levels of 
Code Switching on EFL Student's Daily Language; Study of Language Production".

The factor and reason of applying code switching in the English Language Education students' daily communication.

In finding the data that can answer the question in this part, the writer used the interview method. Their answers are various.
The reasons of students of doing code switching are classified by the writer based on the factors related. The following is the classification of their responds or answer when the writer ask about the factors or the reasons of switching one language code to the other language especially English.

Table 4. Students' reason of using code switching

\begin{tabular}{|c|c|}
\hline Social Factor & \multicolumn{1}{|c|}{ Students Reason } \\
\hline $\begin{array}{c}\text { Internal Psycholinguistics } \\
\text { Factor }\end{array}$ & $\begin{array}{l}\text { 1. "I usually did the code-switching because I am } \\
\text { unconscious. The utterance is just produced without } \\
\text { any longer time of thinking. So it is confortable for me } \\
\text { to switch the code because I often hear that } \\
\text { expression." } \\
\text { 2."I usually switch the language when I want to } \\
\text { emphasize something in my conversation to the other } \\
\text { person. Besides, I also code the language because } \\
\text { sometimes I feel more comfortable when I switch one } \\
\text { language into another in speaking." }\end{array}$ \\
\hline External Social Factor & $\begin{array}{l}\text { "I usually use code switching in my conversation because } \\
\text { I know the person or people that I am talking to will } \\
\text { understand more when I switch a few part of my } \\
\text { utterance to English. Besides, there are also many words } \\
\text { that cannot be translated easily to Bahasa Indonesia } \\
\text { such as e-mail and online. Maybe it can be translated, } \\
\text { but it is uncommon. So for that reason I usually switch } \\
\text { one language into another language. }\end{array}$ \\
\hline
\end{tabular}

Based on the data that is collected from the respondent for the second question, it shows that there are several reasons for them to switch the language. After the writer classified the reasons, it can be concluded that there are two social factors that influence the students to switch one language into the other language. The first one is because the internal psycholinguistics. In this factor, the reason of switching to the language comes from themselves whether it is conscious or not. The second factor is the external social factor. In this factor, the students switch the language because of the other aspect beyond of themselves such as based on the participant, topic, setting and condition.
The influence of switching codes in daily communication toward the students' language skill

In finding the data for this part of question, the writer also did an interview to five ELE students. Most of the students had and gave the similar answer when the writer asked about influence of the use of code switching toward their achievement in the formal class. The very common answer was they said that because of they often switch the language in daily communication, it help them to enrich their vocabulary. It is because that they always remember the certain words that they usually switch. For example they always said "Tunggu sebentar, ini lagi on the way" when their friend is waiting for them. At the first, they only follow Lingua Scientia| 42 
the utterance which shows in a movie that they watch but after that they always use it in daily communication. They get use to say it unconsciously. It can enrich their vocabulary building. Besides, it also helps them in discussing a material or a subject to their friend. They said that they can switch the language to emphasize a certain part of the material by using code switching in order to make their friend understand easily toward the point of material which is discussed. Based on their explanation, it shows that most of the achievement that they get because of applying code switching is enriching their vocabulary building.

\section{CONCLUSION}

Based on this research, the phenomenon of code switching in daily conversation among the English Language Education Students at Universitas Pendidikan Ganesha is commonly used. The level of code switching appears in word level, phrase level and the clause or sentence level based on their need in speaking. In order to switch the language code, there are two factors that influence them to do it such as the internal psycholinguistics factor and the external social factor. If the reason of switching the language comes from themselves, it is called the internal psycholinguistics factor while if the reason is from beyond themselves, it is called external social factor. The use of code switching from Bahasa Indonesia to English or the opposite in daily conversation also can influence their language skill especially the vocabulary class. They feel that their vocabulary building is improving. Besides, they can switch the language in order to emphasize a part of their speech.

\section{REFERENCES}

Becker, K. (1997). Spanish/English Bilingual Code Switching: A Syncretic Model. Bilingual Review , 22(1), 1-36.

Cook, V. (1991). Second Language Learning and Language Teaching. Melbourne: Hodder Headline Group.
Goodman, K., Goodman, Y., \& Flores, B. (1979). Reading in the Bilingual Classroom: Literacy and Biliteracy. Ros-lyn, VA: National Clearinghouse for Bilingual Children.

Greer, T. (2007). Accomplising Identity in Bilingual Interaction: Code Switching Practices Among a Group of Multietnhnic Japanesse Teenagers. Unpublishing Ph.D, University of Southern Queensland Australia .

Meyer, C. F. (2009). Introducing English Linguistics. Cambridge University Press.

Moghadam, S. H., Samad, A. A., \& Shahraki, E. R. (2012). Code Switching as a Medium of Instruction in an EFL Classroom. Theory and Practice in Language Studies, Vol. 2, No. 11, 1799-2591, doi:10.4304/tpls.2.11.2219-2225.

Muysken, P. (1995). Langauge and Identity in the Assyrian diaspora. In L. Milroy, \& P. Muysken, One Speaker, Two Languages: Crossdisciplinary Perspective on Code Switching (pp. 177-197). New York: Cambridge University Press.

Richard, K. (1985). Principle of particle Construction. In J. Gueron, H. Obenaurer, \& J. Y. Pollock, Grammatical Representation. Dordrecht, The Netherlands: Foris Publication.

Skiba, R. (1997). Code Switching as a Countenance of Language Interference. The Internet TESL Journal, Vol. 3, No. 1.

Yao, M. (2011). On Attitudes to Teachers' Codeswitching in EFL Classes. World Journal of English Language, Vol . 1, No. 1; doi:10.5430/wjel.v1n1p19. 
Zainuddin. (2016). Levels of Code Switching on EFL Student's Daily Language; Study of Language Production. Advances in
Language and Literary Studies, Vol. 7 No. 3, 2203-4714, Doi:10.7575/aiac.alls.v.7n.3p.278. 